Louise Burenby, Timo Partonen, Timothy R. Carter, Reija Ruuhela, Jaana Halonen

\title{
Climate Change and Mental Health
}

There is a gap in the knowledge concerning the long-term and gradual impacts of climate change on mental health. This discussion paper summarises the expected impacts of the ongoing climate change on mental health in Finland.

This discussion paper is intended to open the discussion concerning mental health on the actions and concrete measures we need for mitigation and adaptation to the ongoing climate change in Finland. It provides nine science-based recommendations for implementation in the integrated services for social affairs and health in Finland. 


\section{Foreword}

Attention to the influence of climate change on the human health has been paid. However, there is a gap in the knowledge concerning the long-term and gradual impacts of the ongoing climate change on mental health. This is the justification for this discussion paper. It summarises the expected impacts of climate change on mental health in Finland and provides nine recommendations for implementation in the integrated social affairs and health services in Finland.

This discussion paper is intended to open the discussion concerning mental health on the action plans and concrete measures we need for mitigation and adaptation to the ongoing climate change in Finland. It is part of the project Climate change and Health: Adapting to Mental, Physical and Societal challenges (CHAMPS), which is a research consortium funded by the Academy of Finland within its research programme on Climate Change and Health (CLIHE) running from 2020 to 2023.

Helsinki, 2 December 2021

The authors 


\section{Abstract}

Louise Burenby, Timo Partonen, Timothy R. Carter, Reija Ruuhela, Jaana Halonen. Climate change and mental health. Finnish Institute for Health and Welfare (THL). Discussion paper 32/2021. 20 pages. Helsinki, Finland 2021.

ISBN 978-952-343-765-4 (online publication)

This discussion paper opens the discussion concerning mental health on the actions and concrete measures we need for mitigation and adaptation to the ongoing climate change in Finland.

Growing attention to the influence of change on the human health is being paid. Most of this work is concentrated on how the climate change will affect physical health. Thus far, some attention has been paid to the impacts which are related to psychological trauma such as post-traumatic stress disorder due to acute disastrous events of extreme weather conditions.

However, there is a persistent gap in the knowledge concerning the long-term and gradual impacts of the ongoing climate change on mental health. This discussion paper summarises the expected impacts of climate change on mental health in Finland and provides nine science-based recommendations for implementation in the integrated social affairs and health services in Finland.

Keywords: global solar radiation, global warming, health care, policy, seasonal affective disorder, social care, suicide, shared socioeconomic pathway, urban heat island, vulnerability 


\section{Tiivistelmä}

Louise Burenby, Timo Partonen, Timothy R. Carter, Reija Ruuhela, Jaana Halonen. Climate change and mental health [Ilmastonmuutos ja mielenterveys]. Terveyden ja hyvinvoinnin laitos (THL). Työpaperi 32/2021. 20 sivua. Helsinki 2021.

ISBN 978-952-343-765-4 (verkkojulkaisu)

Tämä työpaperi avaa mielenterveyttä koskevan keskustelun niistä toimista ja käytännön toimenpiteistä, joita tarvitsemme ilmastonmuutoksen hillitsemiseksi ja siihen sopeutumiseksi Suomessa.

Meneillään olevan ilmastonmuutoksen terveysvaikutuksiin kiinnitetään yhä enemmän huomiota. Suurin osa työstä keskittyy siihen, miten ilmastonmuutos vaikuttaa fyysiseen terveyteen. Jonkin verran huomiota on toistaiseksi kiinnitetty myös niihin vaikutuksiin, jotka liittyvät psyykkisiin traumoihin, kuten äärimmäisistä sääolosuhteista johtuvien katastrofien aiheuttamaan traumaperäiseen stressihäiriöön.

Ilmastonmuutoksen pitkäaikaisista ja asteittaisista mielenterveysvaikutuksista on toistaiseksi vasta niin vähän tietoa, että voimme puhua jopa tietoaukosta. Tämä työpaperi tiivistää ilmastonmuutoksen odotetut mielenterveysvaikutukset Suomessa ja antaa yhdeksän tiedeperustaista suositusta integroituihin sosiaali- ja terveyspalveluihin.

Avainsanat: globaalisäteily, haavoittuva, ilmaston lämpeneminen, itsemurhakuolema, jaettu sosioekonominen polku, kaamosmasennus, lämpösaareke, politiikka, sosiaali- ja terveyspalvelut 


\section{Sammandrag}

Louise Burenby, Timo Partonen, Timothy R. Carter, Reija Ruuhela, Jaana Halonen. Climate change and mental health [Klimatförändringen och psykisk hälsa]. Institutet för hälsa och välfärd (THL). Diskussionsunderlag 32/2021. 20 sidor. Helsingfors, Finland 2021.

ISBN 978-952-343-765-4 (nätpublikation)

Detta diskussionsunderlag inleder diskussionen om psykisk hälsa om de åtgärdsmotion och konkreta åtgärder vi behöver för att mildra och anpassa oss till den pågående klimatförändringen i Finland.

En växande uppmärksamhet ägnas åt påverkan av den pågående klimatförändringen på hälsa. Det mesta av detta arbete är koncentrerat till hur klimatförändringen kommer att påverka den fysiska hälsan. Hittills har viss uppmärksamhet ägnats effekterna som är relaterade till psykiska trauman såsom posttraumatisk stressyndrom på grund av akuta katastrofala händelser av extrema väderförhållanden.

Det finns dock en bestående lucka i kunskapen om de långsiktiga och gradvisa effekterna av klimatförändringen på mental hälsa. Detta diskussionsunderlag sammanfattar klimatförändringens förväntade effekter på mental hälsa i Finland och ger nio vetenskapligt baserade rekommendationer för implementering i den integrerade social- och hälsovården i Finland.

Nyckelord: delad socioekonomisk väg, global uppvärmning, politik, självmord, social- och hälsovårdstjänster, solstrålning, stads värme ö, vinterdepression, ömtålig 


\section{Contents}

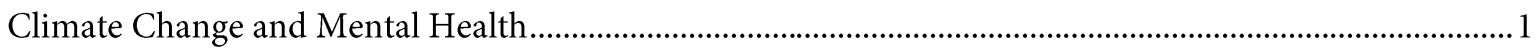

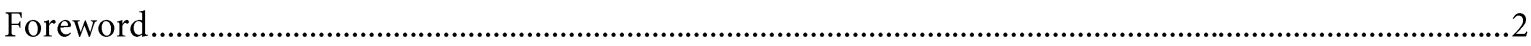

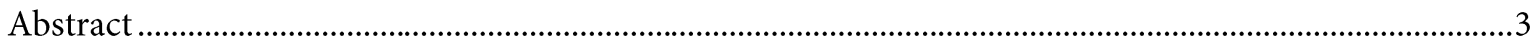

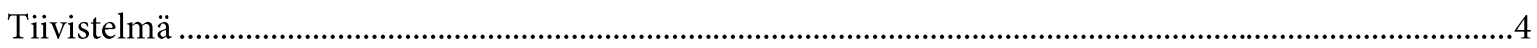

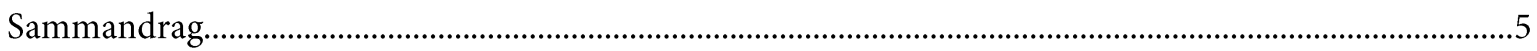

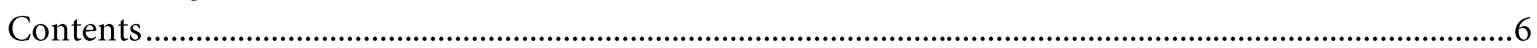

Climate change and mental health ......................................................................................................

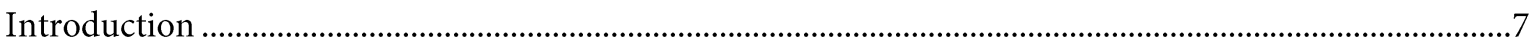

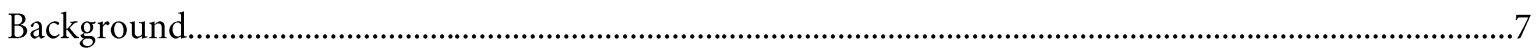

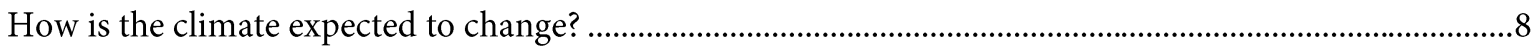

Air temperature

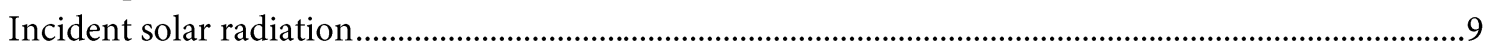

What are the likely impacts on mental health? ..........................................................................................

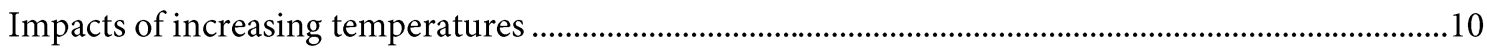

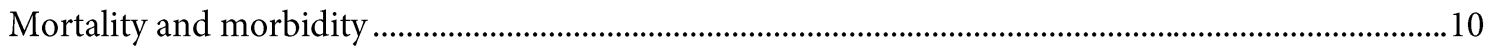

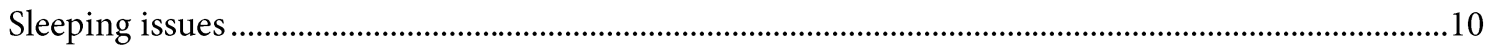

Impacts of changes in solar radiation ..........................................................................................

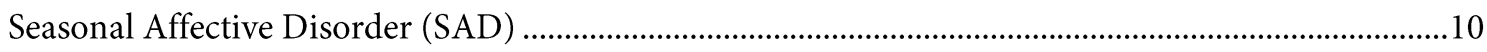

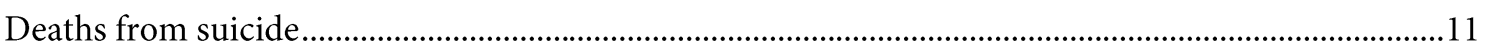

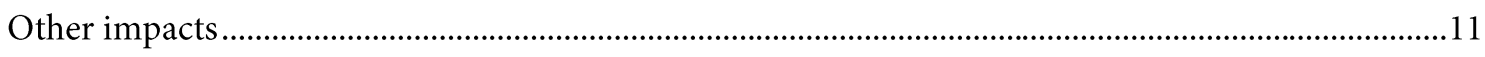

Eco-anxiety

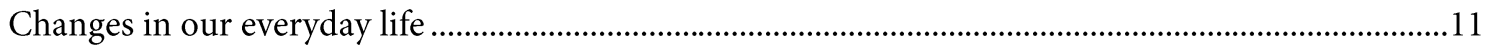

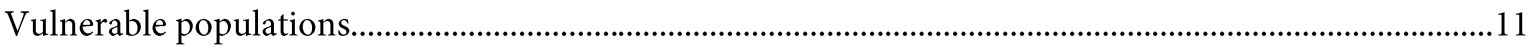

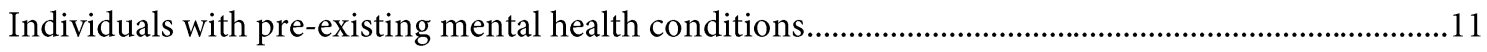

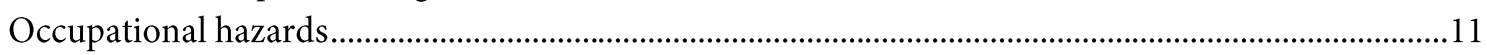

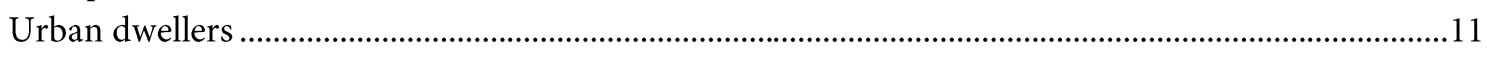

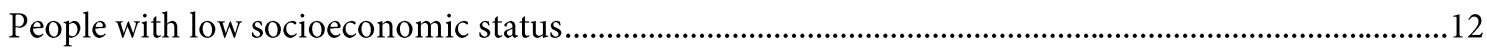

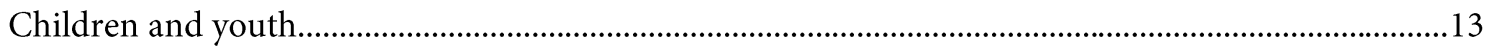

Indigenous people

Current policies in Finland and other settings ..................................................................................13

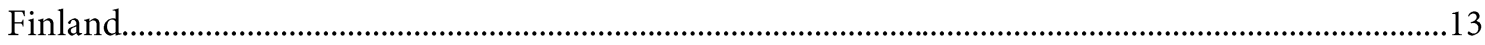

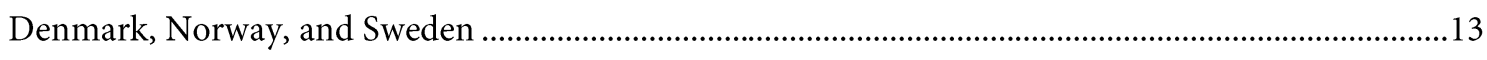

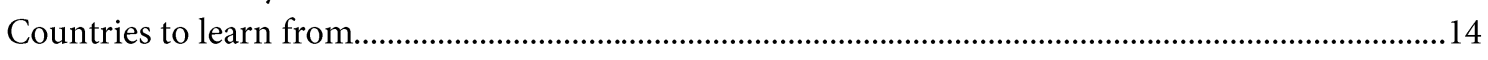

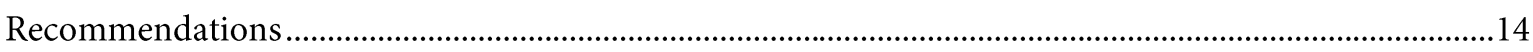

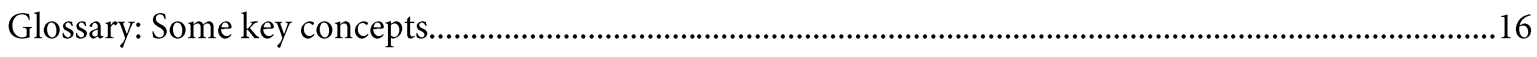

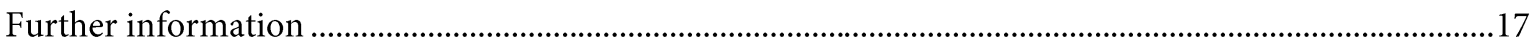

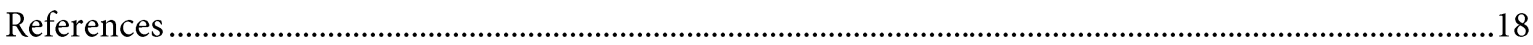




\section{Climate change and mental health}

\section{Introduction}

Authorities around the world are paying increased attention to the impact of climate change on human health. Most of this work is concentrated on how climate change will affect physical health, while some attention is paid to climate change impacts related to trauma, such as post-traumatic stress disorder associated with extreme weather events. There is, however, a persistent gap in the literature concerning the impacts of longterm and gradual climate change on mental health (Charlson et al., 2021; Palinkas \& Wong, 2020; Hayes \& Poland, 2018; Liu \& Zahner, 2020; Rohat et al., 2019).

Since relatively little research has been conducted on gradual climate change and mental health in the Nordic context and there is mounting evidence on its potential importance, there are good grounds for arguing that the topic merits a higher priority in Finland. However, to develop strategies for adapting to climate change in the health care and social welfare sector in Finland, the research which has been conducted in other settings can help to guide the planning of measures in the context of existing scenarios (Charlons et al., 2021; Grimaldi et al., 2009; Lansdall-Welfare et al., 2019; Ruuhela et al, 2008; Lõhmus, 2018). This discussion paper therefore summarizes the current research on expected climate change in Finland and its association with mental health and presents recommendations to be implemented in the integrated social and health care services in Finland.

\section{Background}

Climate change has been described as "the biggest global health threat of the 21st century" (Costello et al., 2009), and for the upcoming COP26 climate summit, in November 2021, more than 200 health journals, among them the Finnish Medical Journal (Lääkärilehti), published an editorial calling on leaders to take emergency action on climate change to protect health. Climate change poses a set of risks to our physical and mental health, but a large part of the existing literature on the subject is focused primarily on physical health, such as air pollution due to forest fires or water contamination due to flooding, and increases in vector borne diseases (Hayes et al., 2018). Although the impacts on mental health are expanding, the focus is often mainly on extreme weather events and their acute psychological effects, such as post-traumatic stress disorder in the wake of hurricanes. What is often neglected, however, is the association between gradual climate change and mental health (Charlson et al., 2021; Palinkas \& Wong, 2020; Hayes \& Poland, 2018; Liu \& Zahner, 2020; Rohat 2019).

The consortium research project CHAMPS investigates how the consequences of gradual climate change expected in Finland may affect mental health and well-being, specifically focusing on increasing temperature and changes in solar radiation. These are important dimensions of climate change to include, even if they are not acute hazards like floods or forest fires. Without long-term planning and concerted actions, we jeopardise the development of rigorous approaches to manage the complex mental health issues which long-term and gradual climate change may create.

Work in CHAMPS seeks to raise awareness, to provide information and to give recommendations for adaptation and preventative measures beyond the countermeasures for acute climate change consequences on mental health. To anticipate, understand and analyze such upcoming challenges, CHAMPS is applying a global scenarios framework based on Shared Socioeconomic Pathways. This framework assists in understanding how different actions and decisions made today will frame our future. It allows us to appraise the scientific uncertainties surrounding future changes in climate over Finland. Further, it helps us understand how different future scenarios of socioeconomic development could affect different groups in society, and how climate change may reinforce or reduce existing health problems and inequities. CHAMPS highlights the integrated approach and emphasizes the need for preventative measures as well as collaboration in society, which are fundamental concepts in building resilient and sustainable public social and health services. 
This discussion paper is one in a series of reports that will be delivered by the CHAMPS project, summarizing existing research on expected climate changes in Finland and their potential impacts on mental health. The paper aims to provide information of potential use to decision makers and health care professionals. That said, societies need to apply integrated perspectives to handle the climate change crisis and its impact on human well-being.

Therefore, we need strong policy coherence, and a strong Health in All Policy approach. To improve population health and health equity, this means that all dimensions of sustainable development should be integrated at all stages of domestic policy making, and that public policy across authority sectors systematically takes the health implications into account in all its decisions (Cocsieme, et al., 2021 \& Ramirez-Rubio, 2019).

\section{How is the climate expected to change?}

There has been extensive work during the past three decades to investigate projected future climate in Finland under scenarios of changing greenhouse gas concentrations in the atmosphere (e.g., Kettunen et al., 1988; Carter et al., 1996; Jylhä et al., 2004; 2009; Ruosteenoja et al., 2016; Ruosteenoja, 2021). Projections are primarily from global climate models (GCMs), but in some cases GCM projections have additionally been downscaled to a finer spatial resolution using regional climate models (RCMs). Climate models have been refined over time, with the latest projections based on SSP-based greenhouse gas scenarios reported by the Intergovernmental Panel on Climate Change in July 2021 (IPCC, 2021).

The main findings for Finland have not changed substantially over successive generations of model projections. Changes in climate are generally greater under scenarios of higher greenhouse gas emissions, but seasonal and regional patterns of change are similar. Here, we illustrate changes by the end of the 21 st century for an intermediate (RCP4.5) scenario (see Figure 1), focusing on two climatic variables relevant for this report in the context of human health: air temperature and incident solar radiation (Ruosteenoja et al., 2016). We also report changes in precipitation that are relevant for projections of radiation.

\section{Air temperature}

Air temperatures are expected to increase in the future at rates faster than the global average, with warming greater in the winter than the summer. Downscaled RCM results suggest stronger winter but weaker summer warming than from GCM results (Figure 1, top left). Warming is also projected to be greater in northern than in southern Finland (not shown in Figure 1). In the summer months periods of heat are projected to become more common and last longer with the highest temperatures being hotter than today. During the winter very low temperatures will emerge less frequently and the snow cover period will become shorter. Thus, thermal seasons will change in Northern Europe. Thermal summers will lengthen by about 10 days and winters shorten by $10-24$ days per $1{ }^{\circ} \mathrm{C}$ of warming (Ruosteenoja et al 2019). 

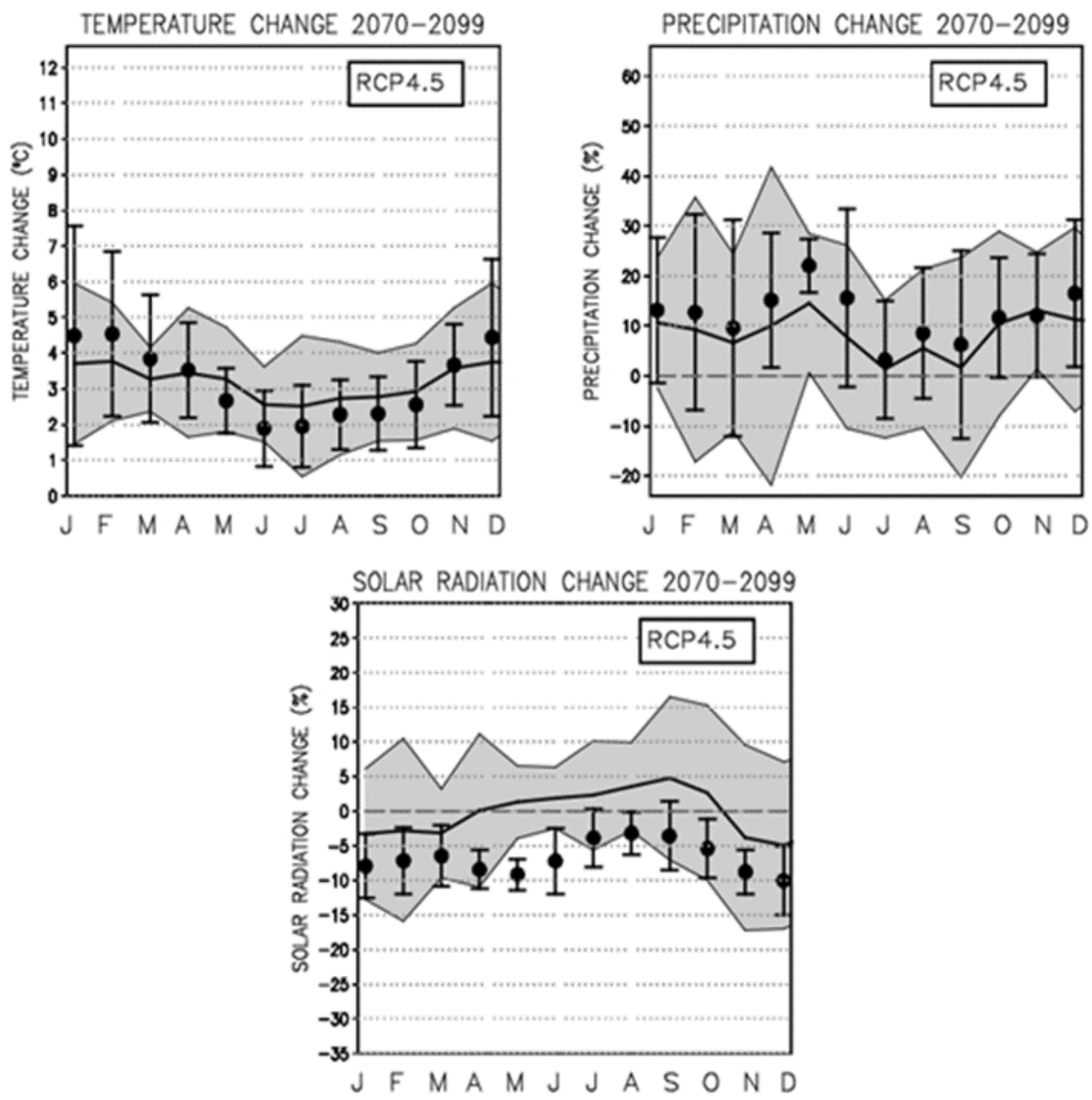

Figure 1. Monthly mean changes in temperature $\left({ }^{\circ} \mathrm{C}\right.$, top left), precipitation (\%, top right) and incident solar radiation (\%, bottom) in Finland for the period 2070-2099 (relative to 1981-2010) under RCP4.5 derived from nine driving GCMs and from the corresponding simulations downscaled by the RCA4 regional climate model. The thick curve is the mean of the GCM projections; grey shading shows $90 \%$ uncertainty intervals. Averages of the RCM responses are shown as bullets and corresponding uncertainty intervals as vertical bars. Source: Ruosteenoja et al. (2016).

\section{Incident solar radiation}

Projections of solar radiation incident at the Earth's surface are somewhat more uncertain than for temperature. Solar radiation is expected to diminish in the winter but the direction of changes in summer is less certain, with a majority of GCMs projecting small increases. This contrasts with downscaled RCM results that suggest a more general decline, though still less than in winter (Figure 1, bottom). Changes are again stronger in the north than the south.

The winter decline expected in solar radiation is closely related to increased cloudiness, which is also reflected in precipitation totals. Precipitation is expected to increase annually, with the greatest and most unambiguous increases in winter (Figure 1, top right). Most GCMs also project increases in the summer, though smaller in magnitude. Downscaled estimates suggest enhanced increases in precipitation throughout the year relative to the GCM results (Figure 1, top right). Consistent with temperature and radiation, projected changes in precipitation are greater in the north than the south. 


\section{What are the likely impacts on mental health?}

The projected climate changes concerning Finland as described above, i.e., increasing air temperatures and changes (mainly declines) in solar radiation, are likely to have a negative impact on the mental health of the population in several ways. Below is a description of the various forms of mental illness that are related to these climate changes.

\section{Impacts of increasing temperatures}

\section{Mortality and morbidity}

The health-related effects of heat are one of the most tangible and significant consequences of climate change. For instance, the European heat wave of 2003 by some estimates caused 70,000 additional deaths in 16 European countries (Robine et al., 2008). Although the high mortality rate during the 2003 heat wave mainly affected central Europe, countries with a cooler climate are not unaffected by this issue. A study by Kollanus \& Lanki (2014) assessed that a single prolonged heat wave in Finland could potentially cause hundreds of premature deaths. This is important in relation to mental health, since people with mental disorders are overrepresented in heat-related morbidity and mortality data, due to their physical and mental capacities to adapt and protect themselves (Lõhmus, 2018; Palinkas \& Wong, 2020; Kollanus et al. 2021).

A study conducted in Sweden found that there was a link between increased temperatures and daily visits to a psychiatric emergency unit in Gothenburg (Carlsen et al., 2019). In Finland, temperature variability explained more than $60 \%$ of the total suicide variance over several decades (Helama et al., 2013). Similar findings have been shown in the USA and Mexico, where suicide rates were found to increase by $0.7 \%$ and $3.1 \%$, respectively, for a $1{ }^{\circ} \mathrm{C}$ increase in monthly average temperature (Burke et., 2018).

However, it is important to note that higher temperatures are also linked to increased psychological distress in persons without pre-existing depression or anxiety and may therefore constitute a risk to the general population, not only at-risk-populations (Charlson, 2021).

\section{Sleeping issues}

Temperature is one of the most important determinants of sleep quality, where increased temperatures and heat waves have been linked to sleep disturbances (Joshi et al., 2016). Sleep and emotion interact, and there is clinical evidence to suggest that nearly all psychiatric and neurological disorders, from schizophrenia to dementia, are associated with problems of sleep. Studies report a two-fold risk of depression among people suffering from insomnia, and sleeplessness in general has been associated with self-harm among youth. There is also evidence that sleep deprivation has a negative impact on cognitive capacity (Lõhmus, 2018). Increasing temperatures in Finland may affect sleep at population level and can potentially lead to a range of mental health issues among people with, as well as without, pre-existing conditions. In the Nordic countries, overheating of buildings may pose an increasing risk for quality of sleep during heat waves, because of lack of efficient cooling systems (Farahani et al., 2021).

\section{Impacts of changes in solar radiation}

\section{Seasonal Affective Disorder (SAD)}

In Finland, 85\% of the population report seasonal variations in their mood and behaviour, and 9\% have the routine seasonal variations together with a current self-report of depression (Grimaldi et al., 2009). This affects not only the health status of individuals, but also the public health in a society. Mental illness is one of the biggest causes of work disability in Finland today. As future climate change is expected to lead to both a diminished and a shorter time span of snow cover in winter, as well as increased cloudiness and reduced solar radiation (Figure 1, bottom) (Ruosteenoja et al., 2016), the winter season will become darker. The incidence of the season-bound symptoms in mood and behaviour, and even that of SAD is thus expected to increase in Finland (Ruuhela, 2018). 


\section{Deaths from suicide}

In many international studies, suicide rates have shown a seasonal pattern, where winters with low solar radiation levels can increase the risk of suicide. This is a problem especially for countries furthest away from the equator, where winter day-lengths are short (Ruuhela, 2008; Lansdall-Welfare et al., 2019). With winters that are anticipated to be darker in Finland, coupled with increasing temperatures during summer, there is a real risk that suicide rates could increase during both periods.

\section{Other impacts}

\section{Eco-anxiety}

As the existential threat associated with climate change gains increasing attention, and climate changes in our own local environments become increasingly visible, the incidence of climate-related anxiety is expected to increase in Finland. Eco-anxiety encompasses significantly challenging emotions, due to environmental issues and the threats they pose (Pihkala, 2019). Some groups are shown to be more likely to suffer from ecoanxiety. These include children, teenagers, and young adults, people who live close to nature and depend on the climate in their everyday life, such as farmers or indigenous people, as well as those who are involved in climate issues, for example through research or activism (Jaakkola et al., 2018; Ojala, 2019; Pihkala, 2019; Morris et al., 2021). Some of the severe symptoms of climate anxiety are psychosomatic symptoms such as insomnia, depression, anxiety and difficulties to maintain functioning, especially when faced with news about climate change, its consequences and threats (Pihkala, 2019).

\section{Changes in our everyday life}

Climate change impacts our environment and weather and will change everyday life from patterns and levels of consumption to activities such as hobbies and travels. One example is that the changing climate will affect what we can do outdoors. It is important to consider this dimension since outdoor activities, which themselves are important for mental health, also contribute to other fundamental aspects of general well-being such as socialisation and community building. Further, other health hazards associated with factors not included in this discussion paper (such as air pollution, vector borne diseases and water contamination) are also likely to affect mental health in a population. It is presumed that concurrent increases in these would also lead to increased levels of distress and negatively impact well-being (Hayes \& Poland, 2018).

\section{Vulnerable populations}

Climate change may not only trigger new cases of mental illness, but also worsen the situation for those with pre-existing mental health problems. Some of the groups most at risk are described below.

\section{Individuals with pre-existing mental health conditions}

Those with pre-existing mental health problems are especially vulnerable to the mental health impacts of heat and solar radiation, contributing to their higher rates of hospitalizations, morbidity, and mortality. As an example, people with dementia, schizophrenia and substance use disorders are at extra-high risk due to their compromised thermoregulation capacity and heat-related cognitive impairment (Lõhmus, 2018; Palinkas \& Wong, 2020).

\section{Occupational hazards}

Climate change may specifically affect mental health among some occupational groups. Farmers, for example, whose economic status largely depends on environmental conditions, tend to suffer from worries and distress as well as anxiety due to climate change and its impact on their livelihood (Howard et al., 2020).

\section{Urban dwellers}

Built-up areas in the centre of cities tend to warm faster than the suburbs and rural areas, since buildings, streets and surfaces store thermal energy during hot and sunny summer days and do not cool down as 
efficiently during the night. This is called the urban heat island effect (see Figure 2). Overheated cities stress the thermoregulatory system of their inhabitants, and since nights do not provide respite from the heat, this poses a threat to urban dwellers (Mücke, 2020). In Finland, the heat-related mortality risk was found to be substantially higher, and the mortality rates attributable to four intensive heat waves of 2003, 2010, 2014 and 2018 were about 2.5-fold higher in Helsinki than in surrounding areas (Ruuhela et al., 2021).

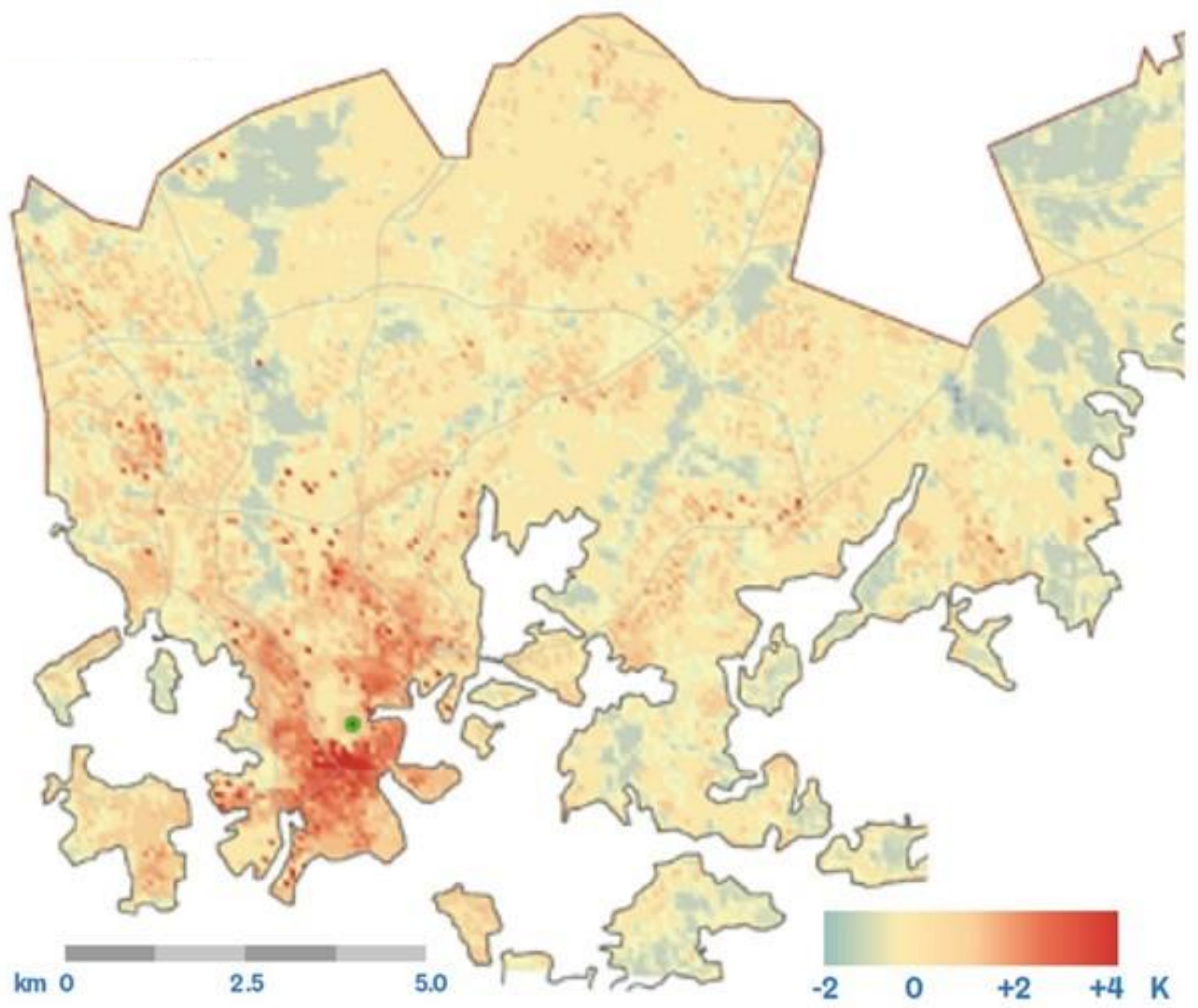

Figure 2. Urban heat islands in Helsinki, Finland, on average between July 2009 and June 2010. The reddest colour indicates areas which are at least 4 degrees warmer than their surroundings. Source: PilliSihvola et al. (2019).

\section{People with low socioeconomic status}

Climate change is a determinant of health status, and it disproportionately affects those who are already the most vulnerable and marginalized in society. Regarding the risks of heat-related health hazards, socioeconomic factors are important drivers (Chen et al., 2018; Rohat et al., 2019). People with a lower socioeconomic status often have fewer resources at their disposal than on average. This means that their ability to act flexibly in a changing situation is limited, since they might not be able to afford a standard of living that shields them from the effects of climate change. For example, without the means to purchase an air conditioner for the hotter summers, people with a lower socioeconomic status may suffer more severely from higher temperatures and have more limited possibilities to adapt. This creates a set of problems needing attention, since climate change is very likely to exacerbate social inequalities that already exist in Finland. However, it is possible to reduce some of these risks and lessen the burden, for example, by ensuring a social security net with accessible health care and good housing. 


\section{Children and youth}

Even though scientific research is limited on the topic, younger generations exhibit increasing distress related to climate change. This is characterised by feelings of sadness, guilt, changes in sleep and appetite, difficulty concentrating and solastalgia - negative perceptions of the actual experience of climate change (Gislason et al., 2021). According to a survey conducted by the association Mental Health in Finland, most young people feel anxious about the environment and the climate in the country (Svenska Yle, 2020). One reason for this may be that children and youth find it more difficult than adults to cope with the negative emotions that climate change arouses (Ojala, 2012). Furthermore, children and adolescents are vulnerable to sleep deprivation, and insufficient sleep is strongly associated with poor mental health and behaviour problems in these groups (Wheaton et al., 2018). Considering how climate change may already impact sleep patterns through increased temperatures, such feelings of stress and anxiety might have a compounding effect, decreasing the overall well-being of younger generations.

\section{Indigenous people}

The Sami population in Finland is relatively small (ca. 10,000 persons), but the Sami people are among the most vulnerable due to the anticipated effects of climate change on their livelihoods, especially on reindeer herding. Many herders in the Sami population have expressed increases in worries, distress, anxiety, and depression due to climate change (Jaakkola et al., 2018).

\section{Current policies in Finland and other settings}

\section{Finland}

It is already anticipated by policymakers that climate change may impact the functioning and reliability of health services in Finland. One of the most current and extensive documents released by the government on the topic in 2021 is the adaptation plan Climate change in the social and health sector - The Ministry of Social Affairs and Health's plan for adapting to climate change. This has been developed within the wider context of adaptation planning in Finland, where the health and social welfare sector has hitherto been regarded as lagging behind many other sectors (Mäkinen et al., 2020). The document targets the social and health services and encourages systematic adaptation by providing practical tools for action. The adaptation plan extends to 2031 and provides a comprehensive description of the expected health-related consequences of climate change. Although more research is required in the Finnish context, mental illness is discussed and anxiety, depression, and suicide as well as eco-anxiety are mentioned (Ministry of Social Affairs, 2021).

The overall goal in Finland is to increase awareness of the importance of climate change for health, and to prevent or alleviate mental health problems. For social and health services there is an emphasis on increasing capacity for individuals to cope with mental disorders due to extreme weather events and improving treatment to prevent the disease burden of heat waves in the summer and depressive episodes in the winter. Furthermore, the importance of counteracting health inequality among the population is also highlighted (Ministry of Social Affairs, 2021).

\section{Denmark, Norway, and Sweden}

Denmark, Norway, and Sweden make similar prognosis as Finland regarding climate change impacts on health. In their climate change adaptation plans, attention is paid most to issues such as water contamination due to flooding, allergies, or vector borne diseases. The psychological consequences of climate change are generally lacking or mentioned in vague terms. However, it is a subject of growing interest and is expected to gain increased space in future reports and adaptation plans (Norwegian Ministry of Climate Change, 2013; Center for International Climate Research, 2018; European Commission, 2018; Regeringen, 2018; Folkhälsomyndigheten, 2021). 


\section{Countries to learn from}

On the other hand, there is research conducted and actions taken in other countries that Finland could learn from. In Canada, for example, a more comprehensive approach to the impacts of climate change on mental health has been called for, as well as long-term perspectives and proactive interventions which include not only emergency response but also the development of broader adaptation (Hayes et al., 2018; Hayes \& Poland, 2018; Hayes \& Poland, 2020). The Canadian Medical Association (CMA) has developed a policy on climate change and mental health, which emphasizes the need for education on the impacts of climate change on health in medical schools and calls for research and increases in data collection as well as a strengthened public health system (CMA, 2010).

Following the heatwave of 2003 in Europe, many European countries implemented Heat-health Warning Systems (HHWS) and Heath-health Adaptation Actions (HHAA) to prevent heat-related morbidity and mortality (Heudorf \& Schade, 2014). The HHWSs and HHAAs use meteorological data to forecast heat waves, warn the population to take countermeasures into action. The actions range from health advice, such as reminding people of increasing their water intake during heat waves, to educational campaigns. Further, there are some intervention strategies concerning work during heat waves, where scheduling heavy work during cooler hours and providing appropriate clothing is recommended (Casanueva et al., 2019).

\section{Recommendations}

Finland may be highly adaptable due to its sound economic starting point as well as being a well-developed society. However, it is of utmost importance to start working on preventive strategies and measures to ensure that Finland's social and health services can meet the needs for mental health care due to climate change (Ministry of Social Affairs, 2021). According to Sellers \& Ebi (2018), moving towards a more sustainable and resilient society and developing climate change strategies is likely to result in better health outcomes. This has been taken into consideration in the recommendations that are presented below.

Research in the CHAMPS project seeks to fill some of the gaps in knowledge identified in this review. However, research has just started, with results only beginning to emerge that will be published during the coming years. Nevertheless, it can be useful, even at this early stage of analysis, to take stock of our current knowledge. Therefore, using the insights gained in this review, we have formulated a list of preliminary recommendations that follow logically from understanding of the likely effects of gradual climate change on mental health.

The recommendations, which are subject to refinement as our knowledge improves, range from strategic approaches to concrete examples of direct measures that can be used to guide future decisions linked to mental illness in the health care sector and social services. The recommendations encourage cooperation between the integrated social and health services and with other administrative sectors in society (e.g., see Mäkinen et al., 2020). It is important for adaptive strategies to ensure that climate change impacts on mental health receive national attention and are not dependent on local interests and resources alone. At the same time, the recommendations highlight the importance of flexibility, so that measures can be taken with local sensitivity and respond appropriately to different needs in different settings. Last, but not least, the recommendations emphasize an intersectoral approach where people from vulnerable groups are given a high priority for prevention of the increased inequity in health which climate change would otherwise cause.

Based on our analysis of the potential risks of long-term and gradual climate change for mental health in Finland, we have identified nine adaptive measures that we suggest are worthy of urgent attention as follows.

1. Increased awareness and competence in the health services: Considering the potential increase of mental health problems due to climate change in Finland, health care professionals and other staff in the integrated social and health services will need to be provided continuous medical education about climate change impacts on mental health. Health care professionals and social care workers play a crucial role in proactive interventions, especially in interactions with risk groups.

2. Improved co-operation between the health services and research: To develop and improve understanding of climate change impacts on mental health, more research is needed. CHAMPS encourages cooperation between the health services and researchers. Through a continuous dialogue, medical 
professionals and researchers can help each other in understanding and assessing the needs and focus areas. Further, the health services play a fundamental role in data collection for research.

3. Improved engagement in decision making: Professionals in the social and health services have enormous collective expertise and experience, which would be of great value in the development of adaptation strategies. To consult them could be important for the implementation of an integrated and coherent approach, both within the sector itself but also where sustainability and mental health are accounted for decision-making across the society.

4. Use of climate information in health care planning: Health and social care planning can be strengthened and improved by the usage of climate data and projections in assessing climate related risks to human health and various activities in health care operations. Based on the risk assessments it is possible to prepare action plans for hazardous short-term weather events or longer-term climatic events with elevated health risks. For example, it is possible to ensure a larger number of staff on call and improve cooling of health care facilities during heat waves. This is important in terms not only of patient safety, but also occupational health and safety, since having sufficient resources reduces stress and burn-out. Climate change scenario data can be used to assess how these risks could change in the future to be prepared for the gradual effects of climate change.

5. Impact-based forecasting as a health intervention: CHAMPS sees that impact-based weather forecasts and climate services tailored for the health sector can be considered as important interventions to prevent adverse health impacts and, thus, improve public health and ensure capacity of health services. This information must be easily available. A good example of such services are the Heat-Health Warning System (HHWS) and Heat-Health Adaptation Action (HHAA) that were developed in many European countries after the 2003 heat wave. HHWSs and HHAAs specifically focus on managing acute heat waves. However, impact-based forecasts and warnings can also be developed for other hazards and impacts and extended to sub-seasonal and seasonal predictions. An example could be early warning of weather conditions expected to intensify psychological distress, like a lack of solar radiation in winter. Co-operation between the Finnish Meteorological Institute (FMI) and the Finnish Institute for Health and Welfare (THL) could be used for prediction and warning of weather events of potential hazard.

6. An emphasis on vulnerable groups and at-risk populations: Some individuals or communities are at high risk of suffering from mental health issues due to climate change. A wide range of factors can impact the vulnerability, ranging from medical conditions to socioeconomic status. The social and health services have a responsibility to pay attention to the vulnerable groups and ensure that they receive the appropriate support.

7. Increased representation in decision making: It is important to identify and understand the obstacles which vulnerable groups are facing and dealing with. Therefore, individuals from these groups with personal experiences need to be invited to share their perceptions and ensure their representation in decisionmaking and strategy development.

8. Use of new technologies: New technologies can help in reducing health-related risks due to climate change and extreme weather. A research project called ClimApp, conducted by universities in Sweden, Denmark, and the Netherlands, developed a mobile phone application which integrates weather forecasts with characteristics of individual users and provides tools for individuals to improve their adaptation when facing climate challenges (https://www.enbel-project.eu/projects-page/climapp). This is a good example of how new technology can support any individual at risk to manage better with hazardous weather events.

9. Comprehensive strategies: To prevent and manage the impacts of climate change on mental health, especially among the most vulnerable, resilient communities can be built by strengthening the health care sector, increasing support to vulnerable groups, and implementing weather-based warning-systems. In addition, feelings of anxiety can be alleviated, for example, by spending time in nature or participating in community programmes, especially in those of resilience building (Hayes et al., 2018; Gislason et al., 2021). Such integrated social and health services can play a key role in not only developing such initiatives, but also connecting people in need. 


\section{Glossary: Some key concepts}

Extreme weather: Extreme weather refers to weather conditions which are anomalously severe in nature or exceptional in its frequency of occurrence or duration. Tornadoes and hurricanes are well-known forms of extreme weather, but long periods of drought and large amounts of precipitation may also be regarded as extreme weather conditions.

Global warming and climate change: The long-term heating-up of our planet is referred to as global warming. Global warming refers to warming caused by human activities, mainly fossil fuel burning, which increases levels of radiatively active (greenhouse) gases that warm the atmosphere. Climate change, on the other hand, refers to human as well as naturally produced variations in the climate that can lead to impacts on natural systems and on human activities on Earth.

Heatwaves: The general description of a heatwave is that it is a prolonged period of hot weather, in relation to what is expected for the area during a particular time of the year. Heatwaves can span from a few days to several weeks. However, there is no formal definition of heatwaves, and many countries have their own thresholds. In Finland, the definition for a hot day ("helle" in Finnish) is when the daily maximum temperature exceeds 25 degrees (in Celsius).

Seasonal affective disorder (SAD): SAD and subsyndromal SAD are terms which describe the levels of changes in mood and behavior that follow a seasonal pattern. SAD was originally defined as a syndrome in which a major depressive episode developed during autumn or winter and remitted the following spring or summer for at least two successive years. In addition, the SAD patient had to show a history of major depressive or bipolar disorder. Subsyndromal SAD is a condition with similar but milder symptoms that do not impair functioning to a major degree nor meet the diagnostic criteria for depressive episodes. In addition, there are seasonal changes in mood and behaviour which are manifested to a different degree in healthy individuals.

Social determinants of health: Social determinants of health refer to the economic and social conditions that influence the health status of people. The socioeconomic position of someone is dependent on several different factors, not only wealth and resources that a person has, but also on political, cultural and societal factors. All these determinants contribute in varying degrees to the health status and well-being of people and are crucial to consider when working for health equity.

SSP-based socioeconomic scenarios: Climate change researchers worldwide are increasingly taking advantage of a global scenarios framework designed around the so-called shared socioeconomic pathways (SSPs). The five SSPs provide alternative global narratives of future socioeconomic outcomes (see Figure 3), in terms of human demographics, economy, lifestyle, policies (excluding climate policies), technology, environment and natural resources. SSP1 visualises a sustainable society with low challenges to adaptation and mitigation regarding climate change. SSP3 features rivalry and protectionism with high challenges to both mitigation and adaptation. SSP4 is characterised by increasing inequity, and high challenges to adaptation but low challenges to mitigation. SSP5 depicts a society where economic and technological development is strong but based on utilization of abundant fossil resources and energy intensively. Challenges in this world are high for mitigation but low for adaptation. Finally, SSP2 characterises a "Middle of the road" pathway with challenges to mitigation and adaptation that are intermediate in between the other four SSPs. All these scenarios are regarded as plausible but have no likelihoods attached to them. The CHAMPS project uses the scenarios framework to understand plausible outcomes of socioeconomic development in relation to climate change. These scenario combinations should not be taken as the goals or targets; rather they are different futures that could result from actions and decisions we take, or do not take. In these different futures, the capacity to mitigate and adapt to climate change can vary wildly. To reach a sustainable future with high mitigation as well as high adaptation capabilities which also aligns with the UN Sustainable Development Goals (https://sdgs.un.org/goals) and with Finland's aim to reduce health status inequity, we need determined 
and purposeful climate policies across administrative sectors, action plans and regulations. The scenarios framework can help to test the robustness of such policies across a range of possible futures. This also applies to policies for addressing climate change impacts on mental health. By linking the expected changes in climate and socioeconomic development in Finland to mental health outcomes, we can work to alleviate negative impacts of climate change on mental health and build up resilience.

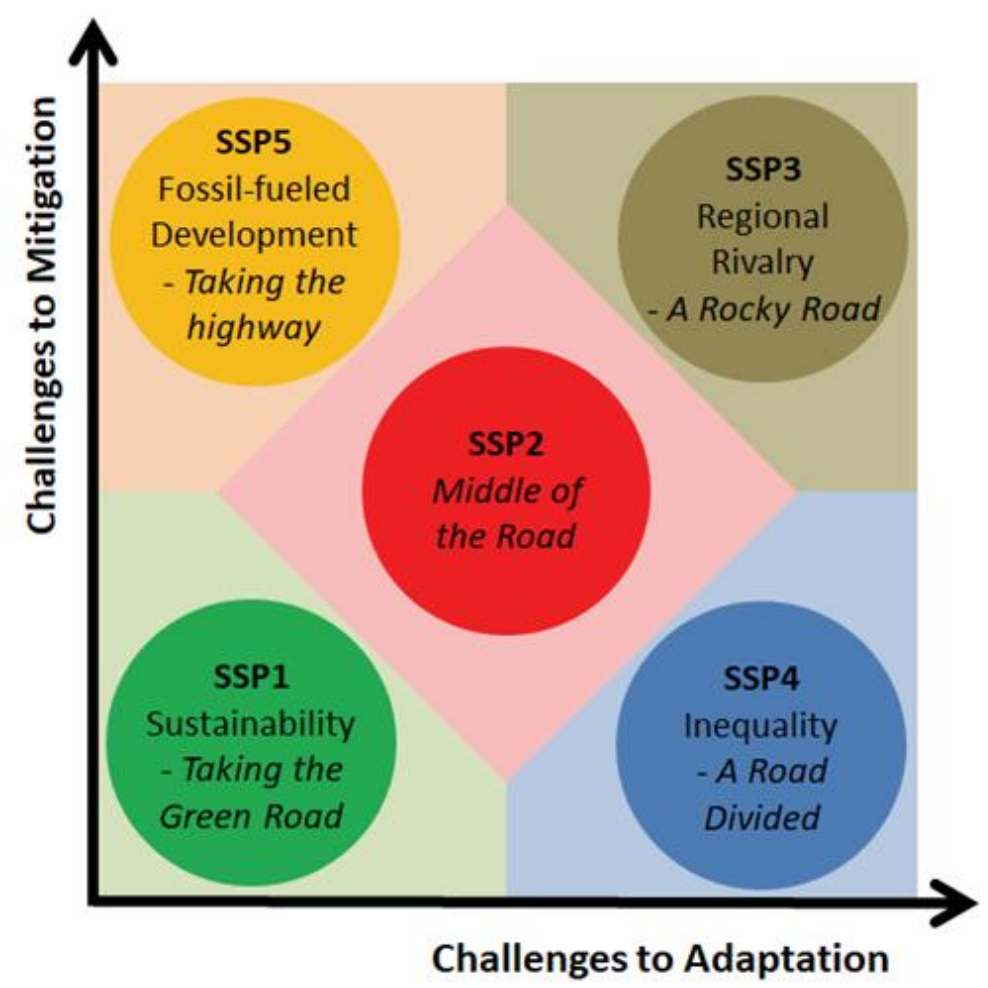

Figure 3. The five shared socioeconomic pathways (SSPs) characterise challenges to mitigation and adaptation. Sources: based on O'Neill et al. (2014) and Frame et al. (2018).

\section{Further information}

CHAMPS is an acronym for "Climate change and Health: Adapting to Mental, Physical and Societal challenges", which is a research consortium funded by the Academy of Finland within its research programme on "Climate Change and Health" (CLIHE) running from 2020 to 2023. The partners of this consortium are the Finnish Environment Institute (SYKE), the Finnish Institute for Health and Welfare (THL), the Finnish Meteorological Institute (FMI), the University of Eastern Finland (UEF), and the University of Helsinki (UH). THL coordinates the CHAMPS project. 


\section{References}

Burke M, González F, Baylis P, Heft-Neal S, Baysan C, Basu S, Hsiang S. Higher temperatures increase suicide rates in the United States and Mexico. Nature Climate Change 2018; 8: 723-729.

Canadian Medical Association. Climate change and human health. Ottawa: Canadian Medical Association, 2010. https://policybase.cma.ca/documents/policypdf/pd10-07.pdf

Carter TR, Posch M, Tuomenvirta H. The SILMU scenarios: specifying Finland's future climate for use in impact assessment. Geophysica 1996; 32: 235-260.

Casanueva A, Burgstall AK, Kotlarski S, Messeri A, Morabito M, Flouris AD, Nybo L, Spirig C, Schwierz C. Overview of existing heat-health warning systems in Europe. International Journal of Environmental Research and Public Health 2019; 16: 2657.

Carlsen HK, Oudin A, Steingrimsson S, Oudin Åström D. Ambient temperature and associations with daily visits to a psychiatric emergency unit in Sweden. International Journal of Environmental Research and Public Health 2019; 16: 286.

Center for International Climate Research CICERO and Vestlandsforsking. Oppdatering av kunnskap om konsekvenser av klimaendringer i Norge. Report 2018:14. M-1209. Trondheim: Miljødirektoratet, 2018. https://www.miljodirektoratet.no/globalassets/publikasjoner/m1209/m1209.pdf

Charlson F, Ali S, Benmarhnia T, Pearl M, Massazza A, Augustinavicius J, Scott JG. Climate change and mental health: a scoping review. International Journal of Environmental Research and Public Health 2021; 18: 4486.

Chen Q, Ding M, Yang X, Hu K, Qi, J. Spatially explicit assessment of heat health risk by using multi-sensor remote sensing images and socioeconomic data in Yangtze River Delta, China. International Journal of Health Geographics 2018; 17: 15 .

Coscieme L, Mortensen LF, Donohue I. Enhance environmental policy coherence to meet the Sustainable Development Goals. Journal of Cleaner Production 2021; 296: 126502.

Costello A, Abbas M, Allen A, Ball S, Bell S, Bellamy R, Friel S, Groce N, Johnson A, Kett M, Lee M, Levy C, Maslin M, McCoy D, McGuire B, Montgomery H, Napier D, Pagel C, Patel J, Puppim de Oliveira JA, Redclift N, Rees H, Rogger D, Scott J, Stephenson J, Twigg J, Wolff J, Patterson C. Managing the health effects of climate change: Lancet and University College London Institute for Global Health Commission. Lancet 2009; 373: 1693-1733.

European Commission. Adaptation preparedness scoreboard: country fiche for Denmark. In: European Commission. Adaptation preparedness scoreboard Country fiches. Commission staff working document. Accompanying the document Report from the Commission to the European Parliamnet and the Council on the implementation of the EU Strategy on adaptation to climate change. SWD(2018) 460 final. Brussels: European Commission, 2018: 150-180. https://ec.europa.eu/clima/system/files/2017-12/dk_en.pdf
Folkhälsomyndigheten. Folkhälsa i ett förändrat klimat: Folkhälsomyndighetens mål och handlingsplan för klimatanpassning 2021-2024. Article number 20207. Stockholm: Folkhälsomyndigheten, 2021. https://www.folkhalsomyndigheten.se/publicerat-material/publikationsarkiv/f/folkhalsa-iett-forandrat-klimat/?pub=88494

Frame B, Lawrence J, Ausseil A-G, Reisinger A, Daigneault A. Adapting global shared socio-economic pathways for national and local scenarios. Climate Risk Management 2018; 21: $39-51$.

Gislason MK, Kennedy AM, Witham SM. The interplay between social and ecological determinants of mental health for children and youth in the climate crisis. International Journal of Environmental Research and Public Health 2021; 18: 4573.

Grimaldi S, Partonen T, Haukka J, Aromaa A, Lönnqvist J. Seasonal vegetative and affective symptoms in the Finnish general population: testing the dual vulnerability and latitude effect hypotheses. Nordic Journal of Psychiatry 2009; 63: 397404.

Hayes K, Blashki G, Wiseman J, Burke S, Reifels L. Climate change and mental health: risks, impacts and priority actions. International Journal of Mental Health Systems 2018; 12: 28.

Hayes K, Poland B. Addressing mental health in a changing climate: incorporating mental health indicators into climate change and health vulnerability and adaptation assessments. International Journal of Environmental Research and Public Health 2018; 15: 1806.

Hayes K, Poland B, Cole DC, Agic B. Psychosocial adaptation to climate change in High River, Alberta: implications for policy and practice. Canadian Journal of Public Health 2020; 111: 880-889.

Helama S, Holopainen J, Partonen T. Temperature-associated suicide mortality: contrasting roles of climatic warming and the suicide prevention program in Finland. Environmental Health and Preventive Medicine 2013; 18: 349-355.

Heudorf U, Schade M. Heat waves and mortality in Frankfurt am Main, Germany, 2003-2013: what effect do heat-health action plans and the heat warning system have? Zeitschrift für Gerontologie und Geriatrie 2014; 47: 475-482.

Howard M, Ahmed S, Lachapelle P, Schure MB. Farmer and rancher perceptions of climate change and their relationships with mental health. Journal of Rural Mental Health 2020; 44: 87-95.

Jaakkola JJK, Juntunen S, Näkkäläjärvi K. The holistic effects of climate change on the culture, well-being, and health of the Saami, the only indigenous people in the European Union. Current Environmental Health Reports 2018; 5: 401-417.

Joshi SS, Lesser TJ, Olsen JW, O'Hara BF. The importance of temperature and thermoregulation for optimal human sleep. Energy and Buildings 2016; 131: 153-157.

Jylhä K, Ruosteenoja K, Räisänen J, Venäläinen A, Tuomenvirta H, Ruokolainen L, Saku S, Seitola T. Arvioita Suomen muuttuvasta ilmastosta sopeutumistutkimuksia varten: ACCLIMhankkeen raportti 2009. Raportteja 2009:4. Helsinki: Finnish Meteorological Institute, 2009.

Kettunen L, Mukula J, Pohjonen V, Rantanen O, Varjo U. The effects of climatic variations on agriculture in Finland. In: Parry ML, Carter TR, Konijn NT (Eds.). The impact of 
climatic variations on agriculture. Volume 1. Assessments in cool temperate and cold regions. Dordrecht: Kluwer, 1988: 511-614.

Kollanus V, Lanki T. 2000-luvun pitkittyneiden helleaaltojen kuolleisuusvaikutukset Suomessa. Duodecim 2014; 130: 983-990.

Kollanus V, Tiittanen P, Lanki T. Mortality risk related to heatwaves in Finland: factors affecting vulnerability. Environmental Research 2021; 201: 111503.

Lansdall-Welfare T, Lightman S, Cristianini N. Seasonal variation in antidepressant prescriptions, environmental light and web queries for seasonal affective disorder. British Journal of Psychiatry 2019; 215: 481-484.

Liu J, Potter T, Zahner S. Policy brief on climate change and mental health/well-being. Nursing Outlook 2020; 68: 517 522 .

Lõhmus M. Possible biological mechanisms linking mental health and heat: a contemplative review. International Journal of Environmental Research and Public Health 2018; 15: 1515.

Ministry of Social Affairs and Health. Climate change in the healthcare and social welfare sector: Climate change adaptation plan of Ministry of Social Affairs and Health (20212031). Publications of the Ministry of Social Affairs and Health 2021:36. Helsinki: Ministry of Social Affairs and Health, 2021. https://urn.fi/URN:ISBN:978-952-00-8424-0

Morris NB, Piil JF, Morabito M, Messeri A, Levi M, Ioannou LG, Ciuha U, Pogačar T, Kajfež Bogataj L, Kingma B, Casanueva A, Kotlarski S, Spirig C, Foster J, Havenith G, Sotto Mayor T, Flouris AD, Nybo L. The HEAT-SHIELD project: perspectives from an inter-sectoral approach to occupational heat stress. Journal of Science and Medicine in Sport 2021; 24: 747-755.

Mücke H-G, Litvinovitch JM. Heat extremes, public health impacts, and adaptation policy in Germany. International Journal of Environmental Research and Public Health 2020; 17 7862.

Mäkinen K, Sorvali J, Lipsanen A, Hildén M. Implementation of Finland's National Climate Change Adaptation Plan 2022: a mid-term evaluation. Publications of the Ministry of Agriculture and Forestry 2020:9. Helsinki: Ministry of Agriculture and Forestry, 2020. http://urn.fi/URN:ISBN:978-952-366198-1

Norwegian Ministry of the Climate and Environment. Climate change adaptation in Norway. Meld. St. 33 (2012-2013) Report to the Storting (white paper). Oslo: Ministry of the Climate and Environment, 2013. https://www.regjeringen.no/en/dokumenter/meld.-st.-33-20122013/id725930/

Ojala M. How do children cope with global climate change? Coping strategies, engagement, and well-being. Journal of Environmental Psychology 2012; 32: 225-233.

Ojala M, Bengtsson H. Young people's coping strategies concerning climate change: relations to perceived communication with parents and friends and proenvironmental behavior Environment and Behavior 2019; 51: 907-935.

O’Neill BC, Kriegler E, Riahi K, Ebi KL, Hallegatte S, Carter TR, Mathur R, van Vuuren DP. A new scenario framework for climate change research: the concept of shared socioeconomic pathways. Climatic Change 2014; 122: 387-400.

Palinkas LA, Wong M. Global climate change and mental health. Current Opinion in Psychology 2020; 32: 12-16.

Pihkala P. Climate anxiety. Helsinki: MIELI Suomen Mielenterveys ry, 2019. https://researchportal.helsinki.fi/en/publications/climate-anxiety

Pilli-Sihvola K, Haavisto R, Leijala U, Luhtala S, Mäkelä A, Ruuhela R, Votsis A. Weather and climate change risks in Helsinki. Publications of the Urban Environment Division 2019:32. Helsinki: City of Helsinki, 2019. https://www.hel.fi/static/liitteet/kaupunkiymparisto/julkaisut/julkaisut/julkaisu-32-19-en.pdf

Ramirez-Rubio O, Daher C, Fanjul G, Gascon M, Mueller N, Pajín L, Plasencia A, Rojas-Rueda D, Thondoo M, Nieuwenhuijsen MJ. Urban health: an example of a "health in all policies" approach in the context of SDGs implementation. Globalization and Health 2019; 15: 87.

Regeringen. Nationell strategi for klimatanpassning. Regeringens proposition 2017/18:163. Stockholm: Regeringen, 2018. http://www.regeringen.se/494483/contentassets/8c1f4fe980ec4fcb8448251acde6bd08/171816300_webb .pdf

Robine J-M, Cheung SLK, Le Roy S, Van Oyen H, Griffiths C, Michel J-P, Herrmann FR. Death toll exceeded 70,000 in Europe during the summer of 2003. Comptes Rendus Biologies 2008; 331: 171-178.

Rohat G, Wilhelmi O, Flacke J, Monaghan A, Gao J, Dao H, van Maarseveen M. Characterizing the role of socioeconomic pathways in shaping future urban heat-related challenges. Science of the Total Environment 2019; 695: 133941.

Ruosteenoja K. Applicability of CMIP6 models for building climate projections for northern Europe. Reports 2021:7. Helsinki: Finnish Meteorological Institute, 2021. http://hdl.handle.net/10138/334477

Ruosteenoja K, Markkanen T, Räisänen J. Thermal seasons in northern Europe in projected future climate. International Journal of Climatology 2019; 40: 4444-4462.

Ruosteenoja K, Jylhä K, Kämäräinen M. Climate projections for Finland under the RCP forcing scenarios. Geophysica 2016; 51: 17-50.

Ruuhela R, Votsis A, Kukkonen J, Jylhä K, Kankaanpää S, Perrels A. Temperature-related mortality in Helsinki compared to its surrounding region over two decades, with special emphasis on intensive heatwaves. Atmosphere 2021; 12 : 46.

Ruuhela R. Impacts of weather and climate on mortality and selfharm in Finland. Finnish Meteorological Institute Contributions No. 147. Helsinki: Finnish Meteorological Institute, 2018. http://hdl.handle.net/10138/258658

Ruuhela R, Venäläinen A, Pirinen P, Hiltunen L, Partonen T. Climate impact on suicide rates in Finland from 1971 to 2003. International Journal of Biometeorology 2008; 53: 167-175.

Sellers S, Ebi KL. Climate change and health under the shared socioeconomic pathway framework. International Journal of Environmental Research and Public Health 2018; 15: 3.

Svenska Yle. Föreningen Psykisk Hälsa i Finland slår larm: "De flesta unga känner ångest över miljön och klimatet". Helsinki: Oy Yleisradio-Rundradion Ab, 2020. 
https://svenska.yle.fi/artikel/2020/01/07/foreningen-psykiskhalsa-i-finland-slar-larm-de-flesta-unga-kanner-angest-over Velashjerdi Farahani A, Jokisalo J, Korhonen N, Jylhä K, Ruosteenoja K, Kosonen R. Overheating risk and energy demand of Nordic old and new apartment buildings during average and extreme weather conditions under a changing climate. Applied Sciences 2021; 11: 3972.

Wheaton AG, Everett Jones S, Cooper AC, Croft JB. Short sleep duration among middle school and high school students: United States, 2015. MMWR Morbidity and Mortality Weekly Report 2018; 67: 85-90. 